\title{
ANÁLISE COMPARATIVA DA DISTRIBUIÇÃO DOS SULFETOS FORMADOS VIA LINGOTAMENTO CONTÍNUO E VIA LINGOTAMENTO CONVENCIONAL NO AÇO SAE 1050*
}

\author{
Vinícius da Silva Madruga ${ }^{1}$ \\ Wagner Viana Bielefeldt ${ }^{2}$ \\ Ayumi Yoshioka ${ }^{3}$
}

\begin{abstract}
Resumo
Os processos de lingotamento contínuo e de lingotamento convencional apresentam diferenças na solidificação dos aços, esse fato tem impacto na distribuição, quantidade e forma de inclusões de óxidos e sulfetos. O objetivo desse trabalho é verificar de que maneira tais diferenças influenciam na distribuição dos sulfetos ao longo do aço solidificado de qualidade SAE 1050. Para isso, 20 amostras foram retiradas de eixos forjados e barras laminadas, produtos conformados de origem do lingotamento convencional e do lingotamento contínuo, respectivamente. As amostras foram analisadas em microscópio ótico e microscópio eletrônico de varredura no modo de análise automatizada de partículas. Através das imagens e de dados numéricos obtidos, foi visto que nas amostras de barra laminada há grande quantidade de sulfetos, se analisada na seção longitudinal, em relação às amostras de eixo forjado. Analisando na seção transversal, foram detectados menos sulfetos devido ao alinhamento dos mesmos. Entre as amostras de eixo forjado, a área ocupada pelos sulfetos é maior no pé do lingote, reduzindo em direção à cabeça, apesar de a cabeça apresentar mais sulfetos. Tais diferenças foram atribuídas à taxa de resfriamento, à seção transversal do produto e ao processo, que variam entre os dois tipos de lingotamento.
\end{abstract}

Palavras-chave: Lingotamento contínuo; lingotamento convencional; aço; sulfetos; óxidos.

\section{COMPARATIVE ANALYSIS OF SULFIDES DISTRIBUTION MADE BY CONTINUOUS CASTING AND BY CONVENTIONAL CASTING ON SAE 1050 STEEL}

\begin{abstract}
The continuous and conventional casting processes shows differences on solidification of steels, this fact has impact on oxides and sulfites distribution, amount and morphology. The main objective is to analyze how these differences have influence on sulfides distribution among the solidified steel quality SAE 1050. Samples were taken from forged axles and rolled bars, products previously made by conventional and continuous casting, respectively. Twenty samples were analyzed in optical microscope and scanning electronic microscope on particles automatic analysis mode. The images and the numerical data show that rolled bar samples have more sulfides than forged axle samples, if the analysis is on axial section. On the cross section, were detected less sulfides because of their alignment. Considering forged axle samples, the widest sulfide area was detected on ingot bottom, reducing in ingot top direction; even the ingot top had presented more sulfides than ingot middle. Cooling rate, cross section product and process can explain these differences, which vary between these types of casting.
\end{abstract}

Keywords: Continuous casting; conventional casting; steel; oxides; sulfides.

1 Metallurgical Engineer, Master Student in Mines, Metallurgical and Materials Engineering PPGE3M/UFRGS, Porto Alegre/RS, Brazil.

2 Professor, Dr., Metallurgical Engineer, Department of Metallurgy and PPGE3M/UFRGS, Porto Alegre/RS, Brazil.

3 Metallurgical Engineer, MSc, Technical Assessor/RD\&l, Special Steels Technology/RD\&l, Gerdau Aços Especiais, Charqueadas, RS, Brazil. 


\section{INTRODUCTION}

Steel is one of the most important raw materials because of its versatility and applicability. In addition, the numbers of steel production are indicators of economic development of a country. It justifies the necessity of some studies made on this area. On solidification processes, there are two routes: foundry and casting, where casting can be divided in continuous casting and conventional casting, as shown on table 1 (1) that presents production data of 2017.

Table 1. Steel production by solidification process (Adapted) - 2017

\begin{tabular}{|c|c|c|c|c|c|c|c|c|c|}
\hline \multirow{2}{*}{ PRODUCTS } & \multicolumn{2}{|c|}{ JAN/FEV } & \multirow{2}{*}{$\begin{array}{c}17 / 16 \\
(\%)\end{array}$} & \multirow{2}{*}{$\begin{array}{l}\text { DEC } \\
2016\end{array}$} & \multirow{2}{*}{$\begin{array}{l}\text { JAN } \\
2017\end{array}$} & \multicolumn{2}{|c|}{ FEBRUARY } & \multirow{2}{*}{$\begin{array}{c}17 / 16 \\
(\%)\end{array}$} & \multirow{2}{*}{$\begin{array}{l}\text { LAST } 12 \\
\text { MONTHS }\end{array}$} \\
\hline & $2017(*)$ & 2016 & & & & $2017(*)$ & 2016 & & \\
\hline \multicolumn{10}{|l|}{-CASTING } \\
\hline CONVENTIONAL & 73 & 63 & 15.9 & 24 & 33 & 40 & 34 & 17.6 & 379 \\
\hline CONTINUOUS & 5,323 & 4,863 & 9.5 & 2,343 & 2,793 & 2,530 & 2,397 & 5.5 & 31,339 \\
\hline -FOUNDRY & 4 & 4 & 0 & 1 & 2 & 2 & 2 & 0 & 27 \\
\hline TOTAL & 5,400 & 4,930 & 9.5 & 2,368 & 2,828 & 2,572 & 2,433 & 5.7 & 31,745 \\
\hline
\end{tabular}

The use of conventional casting is being reduced because of its low productivity, its unstable process and its quality dependent of the operator. However, this casting is necessary to produce ingots, product of large cross-section, usually presents a chemical composition with bad castability (hardly made by continuous casting) and applied to produce special sections, as axles, dies and cylinders. On the other hand, continuous casting produces billets, blocks and slabs, products of thin cross-section, made faster and in great quantity. The next process usually is rolling to continuous casting and forging to conventional casting (2). Considering conventional casting, the biggest challenge is to improve the steel quality, with good chemical homogeneity and mechanical properties as equal as got by continuous casting. The challenge is to reduce the chemical segregation that exists along the solidified steel, phenomenon that occurs during the solidification and forms non-metallic inclusions (3).

\subsection{Segregation}

On continuous casting occurs microsegregation, in other words, segregation between the secondary interdendritic arms. On the other hand, on conventional casting occurs macrosegregation, segregation along the steel part. Besides, segregation can be different in some cases. When there is a higher concentration of solute near the surface than in the centre, the segregation is named as inverse. The negative segregation is when there is less solute in the ingot bottom than the other regions. On the hot ingot top might segregate slag particles (3). Segregation is the driving force to the inclusions formation. Sulfides, oxides and oxysulfides result of chemical reactions that occur during the solidification. In addition, sulfur presents low solubility on steel, which favors its precipitation with a metallic element as sulfide. Commonly, manganese and iron sulfides are formed, but this last one has lower stability and higher hot brittleness than manganese sulfide (4). The formation of iron sulfide is avoided by correct relation \%Mn/\%S on steel. 


\subsection{Spatial distribution of sulfide inclusions on steel}

The distribution is modified by steel manufacture practice. However, the forming processes don't change this characteristic. Sulfides tend to concentrate in the centre of the ingots in low carbon steel. In killed steel, the preferential place to sulfides is near the surface. Figure 1 shows a typical representation of sulfides distribution in a low carbon steel ingot (4).

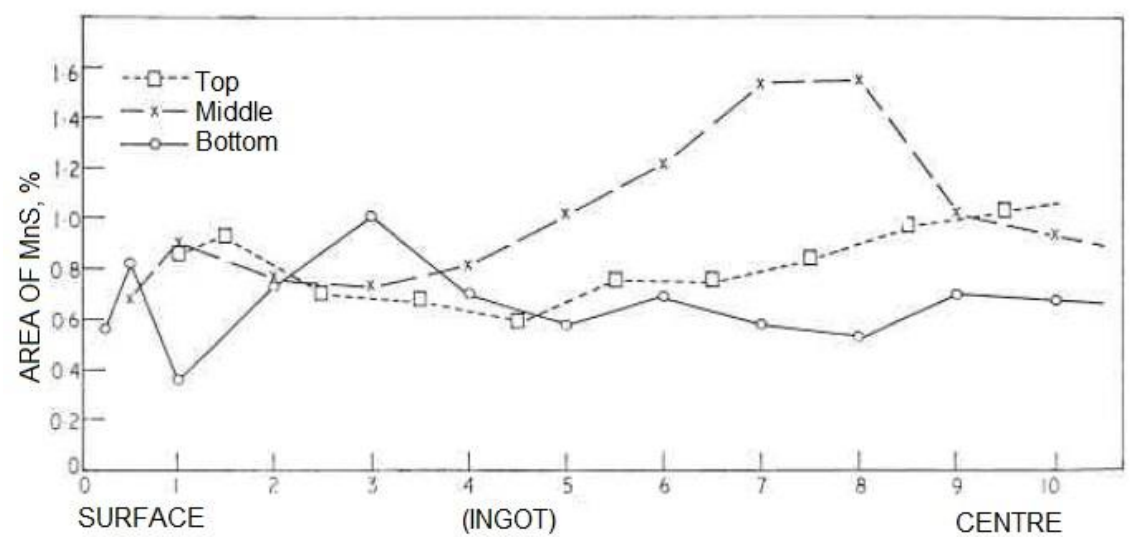

Figure 1. Typical manganese sulfide distribution in steel ingots (KIESSLING; LANGE, 1978).

\subsection{Influence of sulfides on mechanical properties}

Sulfides, as other inclusions, have influence on mechanical properties. Inclusions are stress concentrators points, causing distortion on matrix and making the dislocation passage easier (3). It reduces strength, fatigue and impact resistance. Its influence can be worse depending on inclusion size, shape, quantity and distribution (5), for example, high concentration on the centre, sharp and large shape. In addition, sulfides present good deformability, a characteristic that can be harmful in some applications that require stability (3). Sulfides are always distributed in steel matrix and knowing its characteristics is necessary to get products with higher quality.

The objective of this research is to know the differences on distribution of sulfides during continuous casting and conventional casting on SAE 1050 steel, checking the influence of solidification process and cross-section size related to sulfides distribution.

\section{MATERIALS AND METHODS}

Steel samples analyzed on this research were made in a steel mill. The steelmaking process begins in the choice of raw material (scrap, pig iron and fluxing agents) to make steel on the electric arc furnace. The primary refining is made in this furnace, in other words, decarburization and dephosphorization of steel. After this step, steel is tapped to a ladle, being moved to ladle furnace to secondary refining, which means desulfurization of steel, adjust of chemical composition and temperature. After it, ladle is moved to vacuum degassing to reduce hydrogen, nitrogen and oxygen contents. At last, ladle goes to the next step: casting. There, steel is solidified on continuous or conventional casting, which depends on the final product. The flowchart process is presented on figure 2 . 


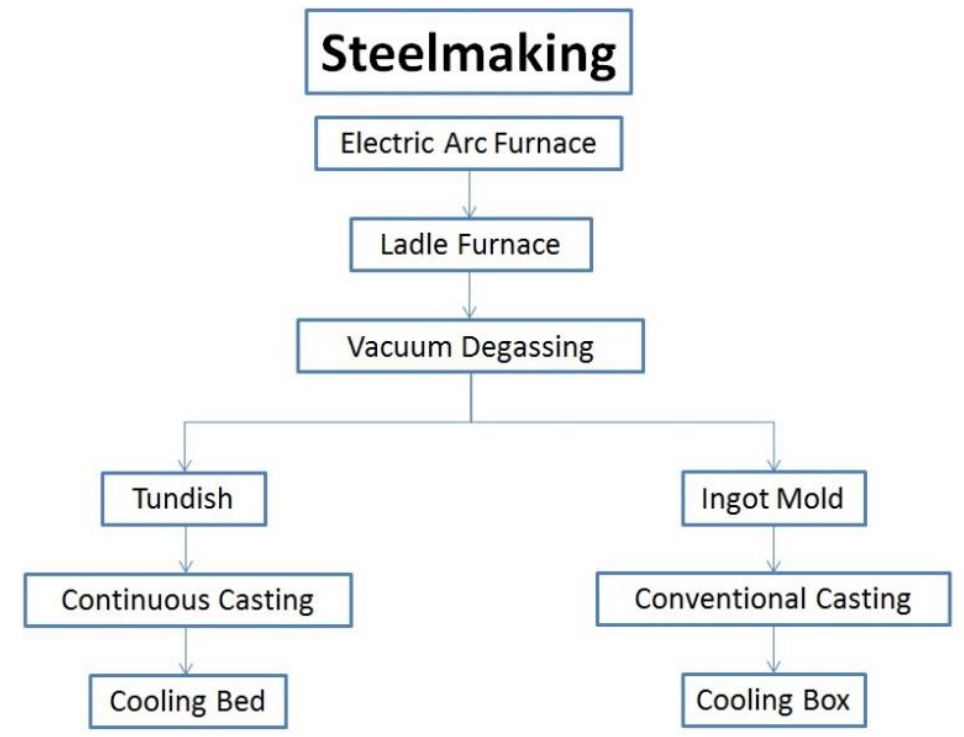

Figure 2. Flowchart process of steelmaking process evaluated in this work.

\subsection{Steel casting}

The steel quality chosen to develop this research was SAE 1050 by two reasons: is made by continuous and conventional casting and is made in large quantity on the steel mill that provided the samples. The SAE 1050 steel is a medium carbon steel, applied to mechanical construction, mainly in automotive sector. From this steel quality is possible to produce crankshaft, connection rod, gear, bearing, screw, sleeve, wheel hub, stringer, steering arm, semiaxle, CV joint ring, manual tool and camshaft. Mechanical strength is one of the most important properties to these parts because of their application, which justifies the importance of inclusions on steels. Liquid steel samples were taken to chemical composition analysis to check the relation $\% \mathrm{Mn} / \% \mathrm{~S}$ is 4 or more to know if it would be formed MnS (6).

The application of ingot mold used in conventional casting is forged parts with crosssection size between 228.7 and $330.2 \mathrm{~mm}$. A set is composed by 4 ingot molds, linked by runners to a gate. Steel is tapped on the gate and the ingots are filled by communication vessels principle. Above the ingot top, occurs the addition of fluxing and killing agents to prevent reoxidation during solidification.

The continuous casting machine is curve and its mold has a square cross-section of $240 \mathrm{~mm}$. This machine has 3 cooling zones: in the mold, in the water sprays zone and in the cooling bed. The tapping of ladle to tundish is made through a long pipe. A lid protects the tundish and steel is tapping through a submerged valve. These resources help to prevent steel reoxidation. Along the solidification process, billet passes for electromagnetic stirring process. The aim is to provide chemical homogenization and to break the columnar structure, resulting in finer grains and chemical composition more homogeneous.

At the end o solidification process, the material produced by conventional casting is formed at forging area and the material produced by continuous casting is formed at rolling mill. After forming process, samples were taken to inclusionary analysis.

\subsection{Sampling}

Samples were taken at forging area (forged axle) and at rolling mill (rolled bar) using saws. The best choice would be to take samples from ingots and billets, but this 
practice was unavailable. However, forming process doesn't change inclusions distribution (4). Table 2 resumes some information about the samples.

Table 2. Samples division by type of forming and by cross-section - 2017

\begin{tabular}{|c|c|c|c|c|c|c|}
\hline No heats & $\begin{array}{c}\text { No } \\
\text { samples }\end{array}$ & $\begin{array}{c}\text { No } \\
\text { samples/ } \\
\text { heat }\end{array}$ & $\begin{array}{c}\text { Size } \\
(\mathrm{mm})\end{array}$ & o samples/size & Region of analysis \\
\hline $\begin{array}{c}\text { Rolled } \\
\text { steel }\end{array}$ & 11 & 11 & 1 & 55.56 & 5 & Indifferent \\
\hline $\begin{array}{c}\text { Forged } \\
\text { steel }\end{array}$ & 3 & 9 & 3 & 267.8 & 9 & $\begin{array}{c}\text { Ingot top, middle } \\
\text { and bottom }\end{array}$ \\
\hline
\end{tabular}

The taken of 3 samples per heat on conventional casting is made to check the differences between the 3 ingot regions on the sulfides formation: top, middle and bottom. In this way, it is possible to preview in which region there was the highest effect of solute segregation. Also, allows comparing sulfides distribution on rolled steel, produced by continuous casting. The chosen region to analyze inclusions follows the ASTM E45 specification (7).

2.2.1 ASTM E45 - Standard Test Methods for Determining the Inclusion Content of Steel. Annual Book of ASTM Standards (2013)

The result of inclusionary level of a metallic alloy is get by inclusion size, and its size is converted to a value that represents counts, length or both, it depends on method chosen to analysis. This specification is used to analyze silicates, oxides and alumina. A sample is proper to be analyzed if it has a minimum surface area of 160 $\mathrm{mm}^{2}$. The analysis is made on the longitudinal area. The difference between the forged axle sample and rolled bar sample is the cross-section. To parts with round section, the sample is $1 / 4$ of cross-section and to parts with large section the sample is taken from half radius. Figure 3 presents the correct cut of samples.
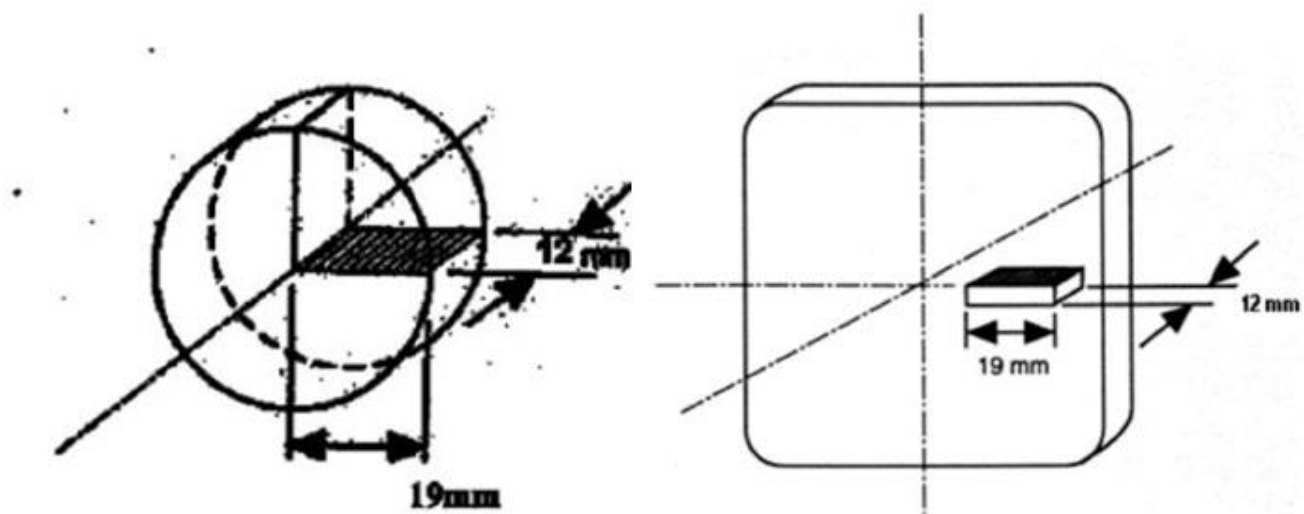

Figure 3. Cut of samples from round section and large section (ASTM E45, 2013).

Sulfides have light gray color on light field analyzed on optical microscope, with long shape in the same direction of forming. The chosen method to analyze sulfides was A (worse fields), where each field of $0.50 \mathrm{~mm}^{2}$ is compared to a pattern to know in which classification that field belongs. The aim is to find the field with the longest and the coarsest inclusions. 


\subsection{Microscopes}

Some microscopes were used to analyze the distribution of inclusions. Optical microscope was used to get results according to ASTM E45, recording images that presented the worst fields. Scanning electronic microscope with automated feature analysis was used to get quantitative results about the distribution of inclusions in each sample. Cross-section of samples were analyzed, considering $62.7 \mathrm{~mm}^{2}$ an acceptable field to get a result. In addition, the sum of manganese and sulfur contents should be higher than $80 \%$ to consider the inclusion as MnS.

\section{RESULTS AND DISCUSSION}

The results were divided in two different analyses: physical distribution and numerical distribution.

\subsection{Physical distribution}

The samples taken from rolled bars and forged axles were analyzed in optical microscope to check the distribution along the fields. Figure 4 shows the images of the worst fields of each sample.

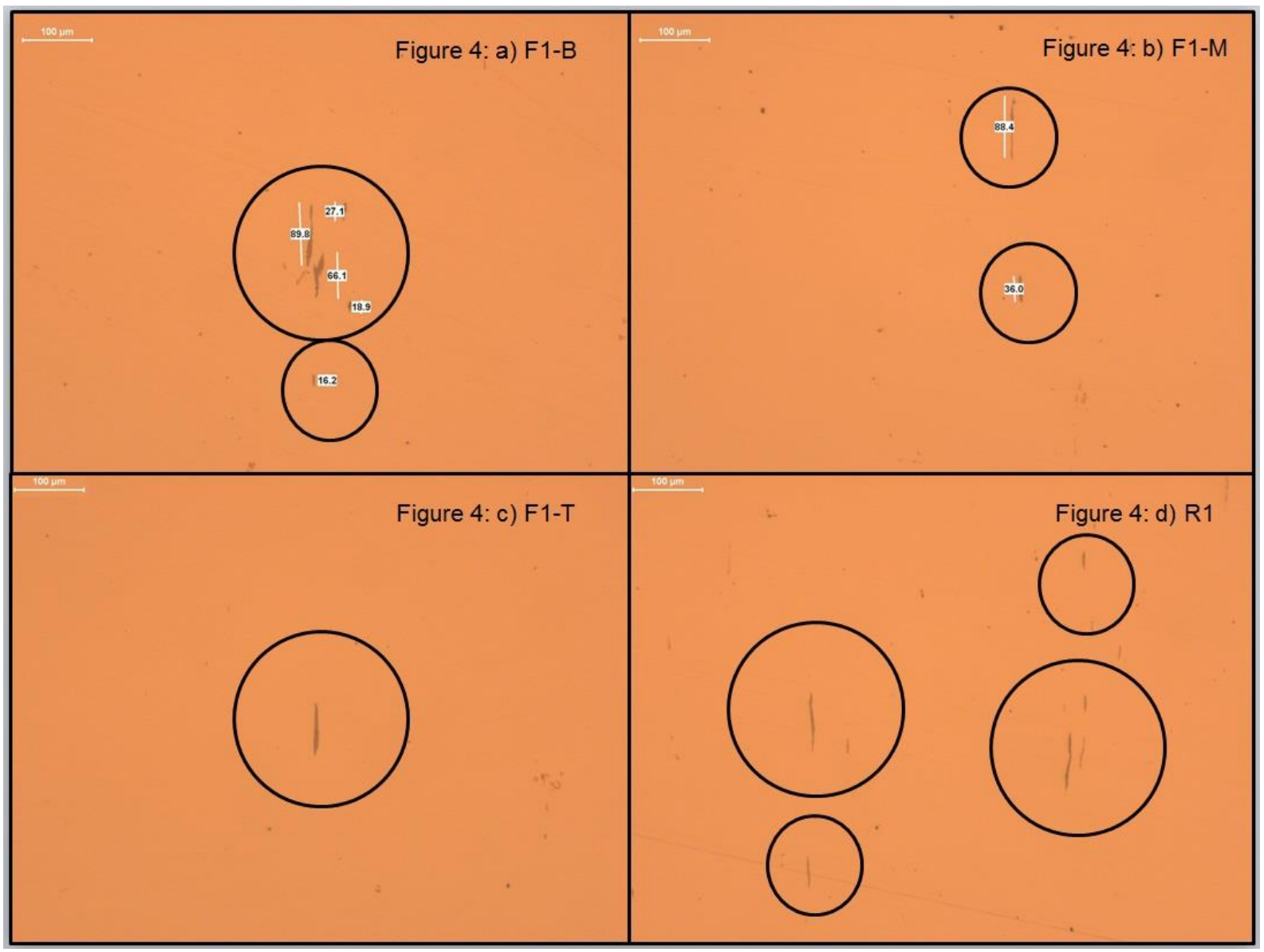

Figure 4. Sulfides inclusions marked on samples taken from (a) the forged axle made from the ingot bottom (F1-B); (b) the forged axle made from the ingot middle (F1-M); (c) the forged axle made from the ingot top (F1-T); and (d) the rolled bar (R1). 
Analyzing the images of samples taken from forged axle, it's seen that there is a higher sulfide concentration on the ingot bottom, reducing in direction to the ingot top. About the length, there are shorter inclusions $(10-30 \mu \mathrm{m})$ in the ingot bottom and their shape is more irregular. Some hypotheses can explain this phenomenon. The first is about the cooling rate that is higher in the ingot bottom than in the other regions. The outer regions solidify before because of conduction effect and, after, the inner regions solidify. The lower regions solidify by conduction and convection effect, while the upper regions solidify by radiation effect. The heat extraction is slower in the upper regions, which allows more time to diffusion of elements and results in a less quantity of sulfides (sulfur concentrates on a specific place). In the lower regions, there is less time to diffusion, presenting more sulfides and spreader. The second is solute segregation, with more sulfur in the lower regions. Apparently, there was positive segregation to the lower regions, with steel liquid being solidified rich in sulfur, different from upper regions, with steel liquid poor in sulfur.

Comparing the images of samples taken from forged axles to samples taken from rolled bars, it's realized that in the rolled bar there are more sulfides and they're longer than in the forged axles. Some factors can explain this difference. The first is the cooling rate. Continuous casting has 3 cooling zones: in the mold, in the water sprays and in the cooling bed. The water sprays zone extracts great heat quantity, being the most significant. In conventional casting the extraction occurs by mold and the hot top. The second is sulfur content in both heats. The sulfur content average in continuous casting heat was 0.024 wt. \%, while in conventional casting heat was 0.008 wt. \%. Thus, it's predictable that would have more sulfides in samples from rolled bars. This difference in sulfur content exists to improve the casting process. The third is the sample that represents the whole part. The sample taken from rolled bars is $1 / 4$ of cross-section bar, while, the sample taken from forged axle is a representation from the middle radius. Furthermore, on the forged part there is a longer path to diffusion occurs, reducing the possibility to concentrate sulfides in any region. It's important to say that samples taken from rolled bars have sulfides with different lengths and it isn't notice very well on samples taken from forged axles. It's supposed that the cooling rate has influence: less time to form sulfur clusters.

\subsection{Numerical distribution}

To this analysis, samples (taken from the forged axle made of ingot bottom - F1-B; taken from the forged axle made of ingot middle - F1-M; taken from the forged axle made of ingot top - F1-T; and taken from rolled bar - R11) were analyzed on scanning electronic microscope on automated feature analysis. Using the features to manganese and sulfur mentioned before, each sample showed some quantity of sulfides in relation to the total number of inclusions, and some sulfides occupied area. Figures 5 and 6 resume these results. 


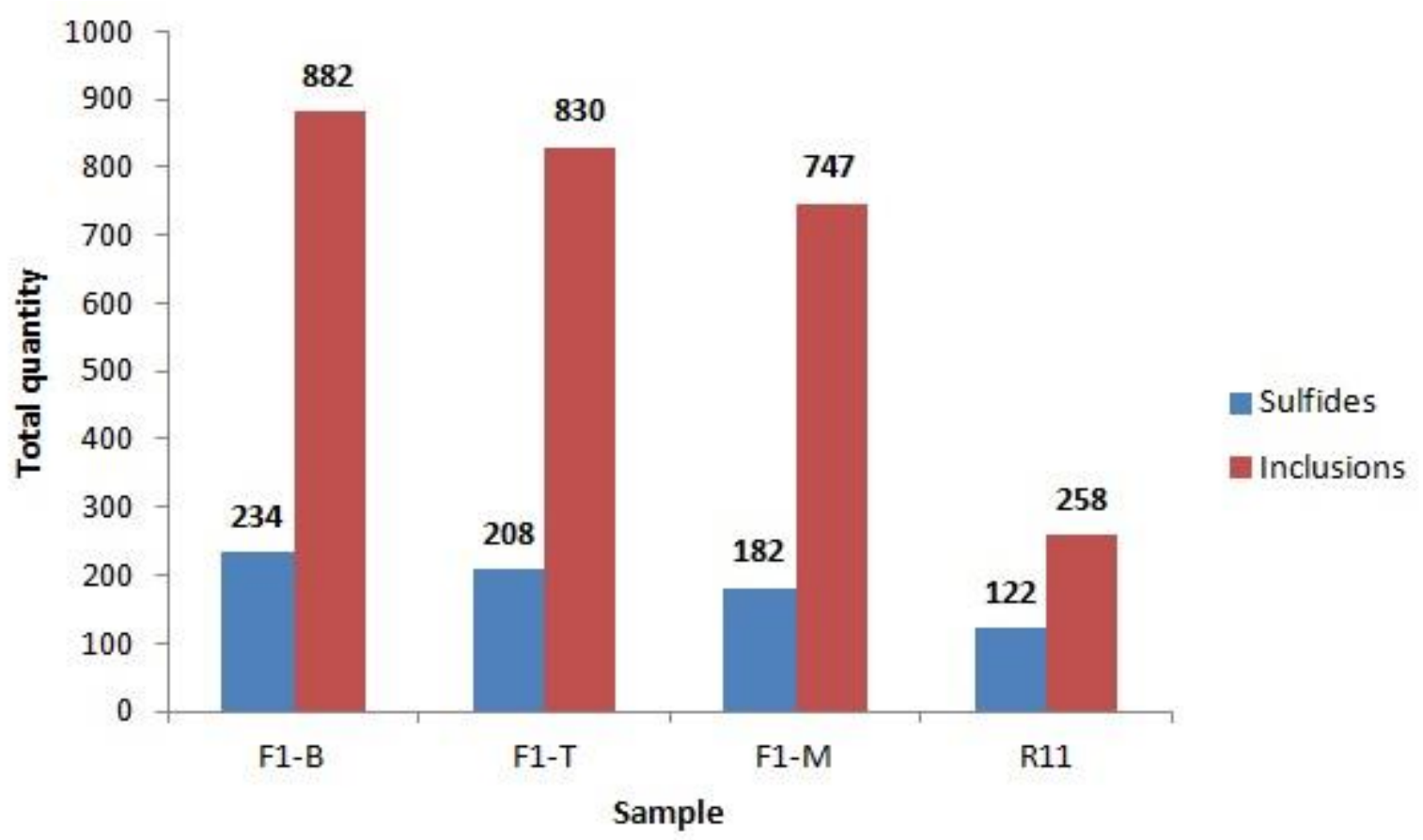

Figure 5. Total quantity of sulfides and inclusions on forged axles samples (F1-B, F1-M and F1-T) and on rolled bar sample (R11).

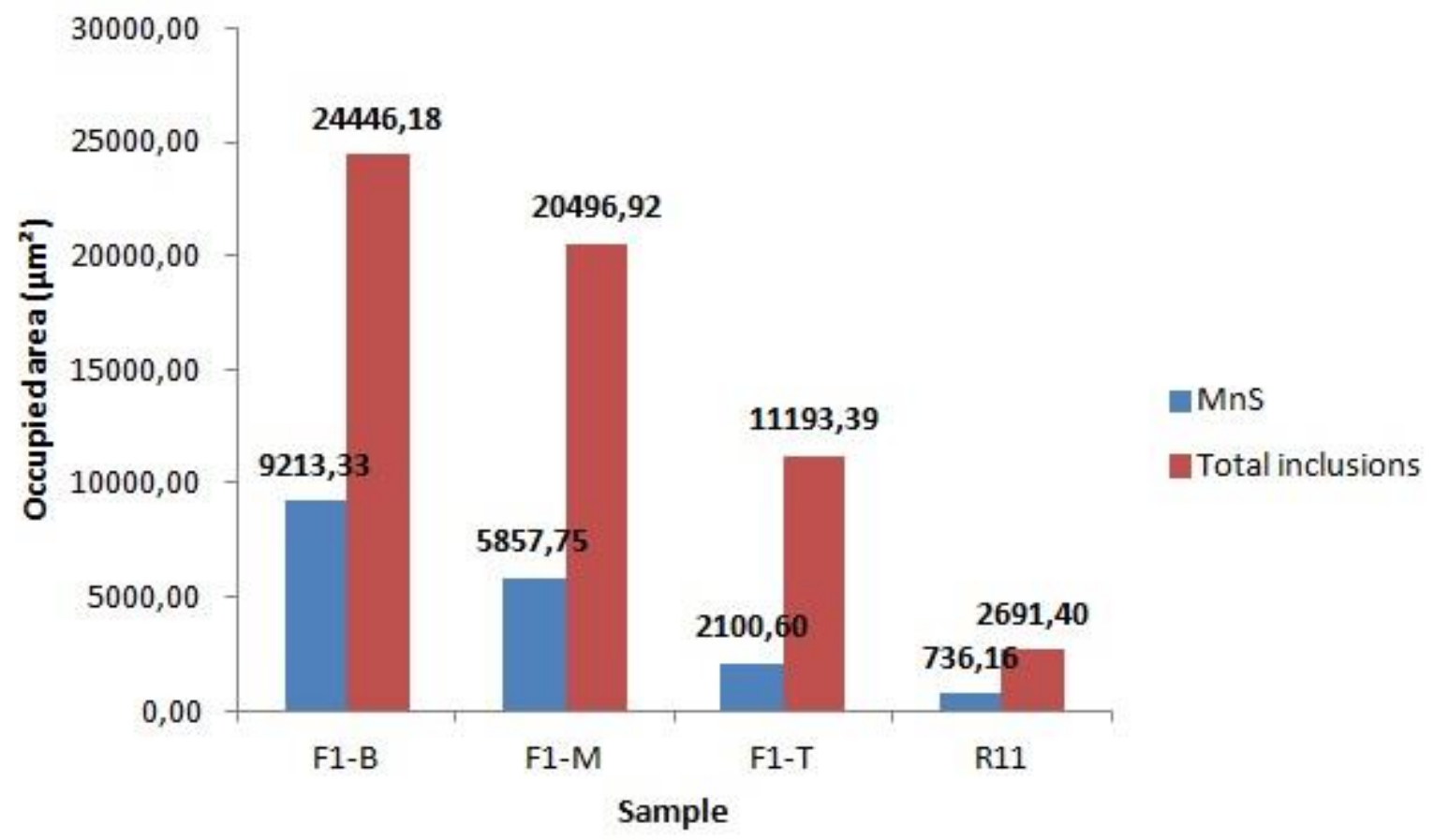

Figure 6. Occupied area by sulfides and inclusions in relation to sample area $\left(62.7 \mathrm{~mm}^{2}\right)$ on forged axles samples (F1-B, F1-M and F1-T) and on rolled bar sample (R11).

It's noticed in figure 5 that the region with the highest sulfide content is on the ingot bottom, followed by ingot top and ingot middle. This result confirms the idea about the segregation and the cooling rate on ingot bottom in relation to other regions in the ingot. However, there is a variation between the numerical and the physical distribution in relation to ingot middle and ingot top. It's supposed that scanning electronic microscope can identify more sulfides and shorter than identified on optical 
microscope. About the rolled bar sample, it presented less sulfides than the other samples. Some hypotheses can explain this. Because of the automated feature analysis, short inclusions were found, being more significant in forged axle samples. Another explanation is the cross-section analysis. On rolled bar, many inclusions, mainly sulfides, tend to stay aligned, characteristic that makes the analysis more difficult, because one sulfide is in front of another. The last is about the inclusionary cleanliness, which could be more efficient on continuous casting. The conventional casting process is more susceptible to reoxidation during the solidifying process.

Figure 6 confirms the statement made to figure 5 . The interesting information is the occupied area by sulfides in the ingot middle is more representative than the top area. Thus, instead of the ingot top presents more sulfides, its area isn't so significant. It's supposed that sulfides in the ingot top are shorter than the sulfides in the ingot middle, resulting in a smaller area.

Comparing all results to figure 1 that presents sulfides distribution along an ingot (1), it's noticed that the result partially matches with literature. It's presumed that samples taken from middle radius matches with the interval between surface and middle radius mentioned on figure 1 . Thus, the occupied area by sulfides is higher on bottom, followed by ingot middle and top, according to results of this research.

\section{CONCLUSIONS}

According the results of this work, the solidification process and cross-section size have influence on distribution of sulfides along the steel SAE 1050.

Considering the physical analysis, the results of the sample taken from rolled bars presents higher content of sulfides, longer, thinner and spreader than the results of the sample taken from forged axles. In the group of samples taken from forged axles, the highest content of sulfides was in the sample taken from the ingot bottom, and this content reduced in direction to the ingot top. The sulfides in the ingot bottom were shorter, thinner and closer one of other than sulfides in the other regions.

Considering the numerical distribution, the samples taken from forged axles presented more inclusions and sulfides comparing to samples taken from rolled bars. The same conclusion is made to occupied area by inclusions and sulfides. In the group of samples taken from forged axles, the sample that had the largest area occupied by inclusions and sulfides was in the ingot bottom. The ingot middle area presented more sulfides, but shorter occupied area than ingot top area.

It is possible to make correlations between differences of process and product that exists between continuous casting and conventional casting, as cooling rate, solidifying process, inclusionary cleanliness and cross-section size of the parts. The results are plausible when compared with literature.

\section{Acknowledgements}

To Gerdau by samples and support along this research; and UFRGS, as well. 


\section{REFERENCES}

1 Estatística Preliminar № 024 Fevereiro 2017. Instituto Aço Brasil. 2017. [acesso em 12 mar. 2017]. Disponível em:

http://www.acobrasil.org.br/site/arquivos/estatisticas/Preliminar_Marco_2017.

2 Rizzo EMDS. Introdução aos Processos Siderúrgicos. São Paūo: Assōociação Brasileira de Metalurgia e Materiais; 2005.

3 Porter DA, Easterling KE, Sherif MY. Phase Transformations in Metals and Alloys. $3^{\text {rd }}$ Edition. Boca Raton: CRC Press; 2009.

4 Kiessling R, Lange N. Non-Metallic Inclusions in Steel. $2^{\text {nd }}$ Edition. United Kingdom: The Metals Society; 1978.

5 Thornton PA. The Influence of Nonmetallic Inclusions on the Mechanical Properties of Steel: A Review. Journal of Materials Science. 1971; 6 (2): 347 356.

6 Müller A. Solidificação e Análise Térmica dos Metais. Porto Alegre: UFRGS; 2002.

7 ASTM E45: Standard Test Methods for Determining the Inclusion Content of Steel. Annual Book of ASTM Standards; 2013. 